ECCOMAS

Proceedia
COMPDYN 2019

$7^{\text {th }}$ ECCOMAS Thematic Conference on Computational Methods in Structural Dynamics and Earthquake Engineering M. Papadrakakis, M. Fragiadakis (eds.) Crete, Greece, 24-26 June 2019

\title{
SEISMIC PERFORMANCE OF PORTUGUESE MASONRY INFILL WALLS: FROM TRADITIONAL SYSTEMS TO NEW SOLUTIONS
}

\author{
Luís M. Silva ${ }^{1}$, Graça Vasconcelos ${ }^{1}$, Paulo B. Lourenço ${ }^{1}$ and Farhad Akhoundi ${ }^{2}$ \\ ${ }^{1}$ ISISE - Institute for Sustainability and Innovation in Structural Engineering \\ University of Minho - Campus de Azurém, 4800-058 Guimarães, Portugal \\ e-mail:1ms@civil.uminho.pt \\ ${ }^{2}$ Faculty of Architecture and Urbanism \\ Tabriz Islamic Art University, Tabriz, Iran
}

\begin{abstract}
The use of masonry infill walls in RC structures is a common solution in Portugal for more than 50 years. These walls are used to build the envelope of the buildings and as interior partitions. Since these walls are built only after the hardening of the $R C$ elements, they are assumed as non-structural elements, and not considered in the structural design.

However, when buildings are subjected to seismic action, these walls assume a structural behavior. This leads in many cases to the existence of an unsatisfactory behavior of infill walls, resulting in damage of the walls, which put human lives in danger and cause extensive economic losses. This seismic vulnerability of masonry infill walls is well recognized by the scientific community and has been observed in the recent earthquakes in southern Europe.

In the case of a seismic event of high intensity in Portugal, it is expected that similar problems will occur in the Portuguese masonry infill walls, given the similarity of the construction typologies, in southern Europe. It is therefore important to study the masonry infill walls used in Portugal over the years, to fully understand their seismic behavior, and thus be able to propose and study new masonry infill systems for new construction.

Thus, in this paper is made a characterization of Portuguese masonry infill walls in terms of evolution over the years. After being presented the problems that arise from the seismic vulnerability of these walls. In an attempt to solve some of these problems is presented in this paper a new system of masonry infill walls, to be used in new construction, with the objective of present a better seismic behavior. Experimental validation of the system is performed, using the in-plane and out-of-plane tests performed at the University of Minho. At the end of the paper, a comparison is made between the new system and the traditional cavity walls, to assess the improvement of the seismic behavior in relation to the traditional solutions.
\end{abstract}

Keywords: Masonry infill walls, In-Plane behavior, Out-of-Plane behavior, Airbag, Experimental characterization, Seismic behavior, Cyclic tests. 


\section{INTRODUCTION}

Masonry infill walls are the most common solution to build enclosures walls in Portugal, mainly in reinforced concrete structures, leading to the need of production of thousands of masonry units annually [1]. In the last 60 years, several authors have carried out studies [2]-[5] to assess the influence of masonry infill walls on the reinforced concrete structure, trying to understand what is their contribution to the lateral strength and stiffness of buildings. According to these authors the masonry infill walls contribute significantly to the performance of buildings and may have a positive influence on the lateral strength and stiffness of buildings, as well as in energy dissipation. However, there are still problems in the behavior of these walls especially when they are subjected to seismic action [6], because masonry infill walls assumes a structural behavior for which they have not been designed. Since masonry infill walls are considered non-structural elements in the current regulations [7], they are not considered in the current structural design practice. Usually there is no verification of their safety against seismic actions. This leads to a high level of damage to moderate earthquakes, resulting in high economic losses and endangering human lives [8]-[10].

The recent earthquakes in Lefkada in 2003 [11], L'Aquila in 2009 [12], Van in 2011 and Emilia Romagna in 2012 [13], among others, have clearly revealed the vulnerability of nonstructural elements in contemporary architecture buildings with reinforced concrete structures. These earthquakes allowed to observe that contemporary structures in reinforced concrete have a reasonable ability to withstand seismic loads, given that were designed for this purpose according to the current design codes [7]. But in the case of masonry infill walls these earthquakes confirmed their vulnerability to seismic actions. The most common pathologies are the separation between masonry panels and structural elements, diagonal cracking, and out-ofplane partial or total collapse. Sometimes it is possible to observe some kind of damage like soft-story or short column associated with the improper use of masonry infill walls.

In the case of a seismic event of high intensity in Portugal, it is expected that similar problems will occur in the Portuguese masonry infill walls, given the similarity of the construction typologies. Despite masonry infills walls being a widely used construction solution in Portugal, the construction systems for this type of walls remains the same for many years, apart from same minor changes. In Portugal the masonry infill walls, had its great advent in the 60 's, with the massification of reinforced concrete structures. Since then until our days the masonry infills walls do not change, apart from same changes in thickness and introduction of thermal isolation between the leafs. The construction system remains based in cavity walls without any connection between leafs, constructed with horizontal perforated bricks and poor mortars. Masonry units have always been ceramic clay bricks, with horizontal perforation and high percent of voids with weak mechanical properties. In Figure 1, it is possible to see the standardized masonry units used in Portugal. However, their vulnerability under seismic actions is recognized by scientific community and proven past earthquakes. Nevertheless, they continue to be used, because until now does not exist any seismic resistant system developed to be used in new construction, with clear design procedures and construction guidelines.

Eurocode 8 [7], is silent in this case and only present a simplified procedure for the calculation of the out-of-plane action, but does not provide design recommendations. On the other hand, this code considers that verification of the safety of non-structural elements is guaranteed if the relative displacements between floors are limited. However, states that appropriate measures should be taken to avoid brittle failure and premature disintegration of infill walls.

To address the existing problems with masonry infill walls, it is important continue the study the masonry infill walls used in Portugal over the years, to fully understand their seismic behavior, and thus be able to propose and study reinforcement systems for existing walls 
and new masonry infill systems for new construction, that can withstand seismic action and propose design guidelines that can be used by structural designers.

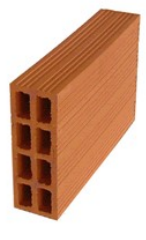

$30 \times 20 \times 7 \mathrm{~cm}$

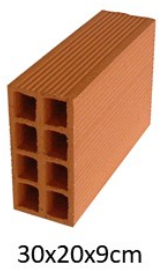

$30 \times 20 \times 9 \mathrm{~cm}$

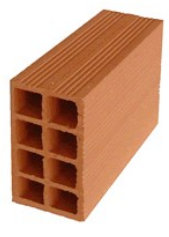

$30 \times 20 \times 11 \mathrm{~cm}$
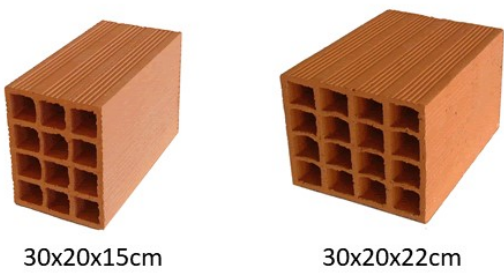

$30 \times 20 \times 22 \mathrm{~cm}$

Figure 1: Horizontal perforated masonry units used in Portugal.

Thus, in this paper is made a characterization of Portuguese masonry infill walls in terms of evolution over the years, and in terms of geometrical characterization. After are presented the problems that arise from the seismic vulnerability of these walls. In an attempt to solve some of these problems is presented in this paper a new system of masonry infill walls, to be used in new construction, with the objective of present a better seismic behavior. An experimental validation of the system is performed, using the in-plane and out-of-plane tests performed at University of Minho.

At the end of the paper, a comparison is made between the new system and the traditional cavity walls, to assess the improvement of the seismic behavior in relation to the traditional solution applied in Portugal.

\section{MASONRY INFILL WALLS IN PORTUGAL}

\subsection{Evolution of Portuguese masonry infill walls}

Masonry infill walls are a very common constructive solution to build the envelope of buildings in Southern and Central European countries, particularly in Portugal, Spain, Italy, Greece among others. This type of walls continues to be widely used, especially in reinforced concrete structures, because they remain an economical and durable solution. In addition, they are relatively easy to construct and provide great architectural freedom and are still capable of meeting a number of requirements such as watertightness, acoustic comfort, thermal comfort, fire safety and good air quality [14].

However, there are several possible solutions to build masonry infill walls. The wide variety of existing mortars and masonry units, as well as the use of connectors and reinforcements make possible the existence of thousands of different combinations that can be translated in different solutions to this kind of walls. Different solutions are often associated with different geographies.

In Portugal the evolution of masonry enclosures walls is linked to the evolution of Portuguese building stock. The most significant moment in the evolution of masonry walls is the transition between the old masonry buildings and the buildings built with in reinforced concrete structure. The massification of reinforced concrete structures, in the late 1940s, first on slabs, replacing the wooden floors, and then on the vertical structural elements, caused masonry enclosures walls to lose their structural function, turning into simple infill elements. This trend occurred in parallel with the declining use of stone, that start being replaced by clay bricks. Clay brick units were developed in different sizes and shapes, progressing from traditional solid small units to large horizontally perforated elements with a high percentage of voids. 
The widespread use of reinforced concrete associated with the importance of maintaining the watertightness of the enclosures led to the generalization of enclosure cavity walls, made of clay bricks, in the 1960s (see Figure 2). The use of cavity walls, in addition to ensuring watertightness, reduce the load on the structure, increase the productivity in construction, reduce costs, simplify the development of works in height.

Since its generalization in the 1960s, the masonry enclosures walls have undergone some evolutions, as shown in Figure 2. The typical 1960s solution is a double wall solution, where the external wall is thicker (usually $0.15 \mathrm{~m}$ ) than the inner wall (usually $0.11 \mathrm{~m}$ ), the wall panels are not connected at all, and the cavity between the walls is filled with air. The masonry units used are horizontal drilling and the mortar was produced on-site.

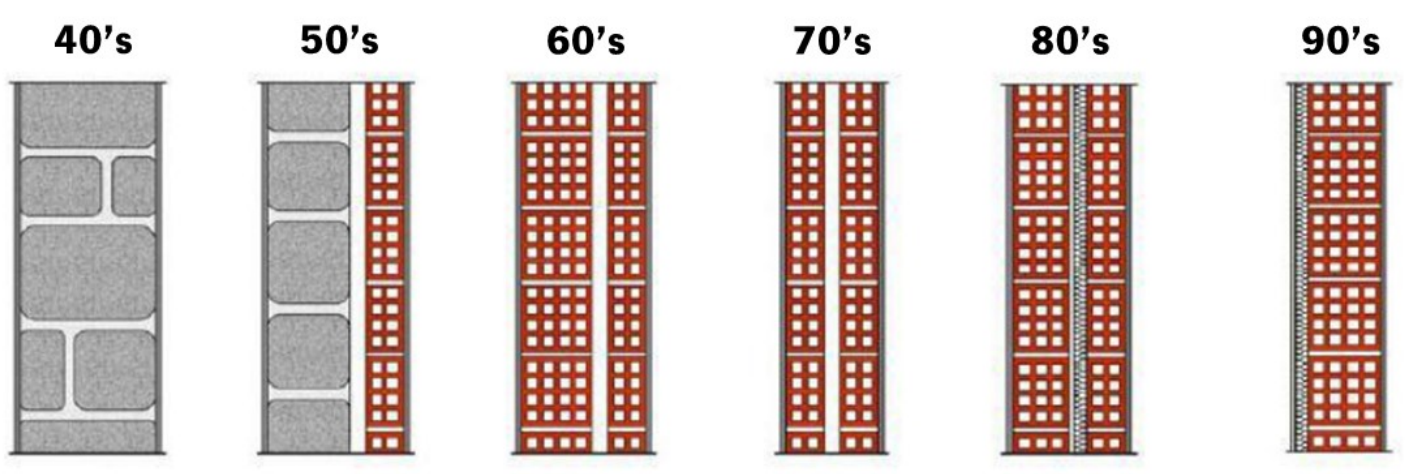

Figure 2: Evolution of masonry enclosures in Portugal (adapted from [15]).

In the 70's a reduction of the thickness (usually $0.11 \mathrm{~m}$ ) of the external leaf was observed, which would increase in thickness in the 80 's, in order to meet the thermal requirements, in addition the cavity between the wall panels, was now filled with thermal insulation. Since the 1990s and nowadays, the cavity wall solution has been replaced by the use of the single wall, using thicker walls, with thermal insulation in external side of the wall [5].

Although horizontal drilling masonry units are still widely used, in recent years the use of so-called thermal and acoustic bricks has been introduced and they have vertical drilling and improved thermal and acoustic properties. In terms of materials throughout all these years the most used masonry units have always been ceramic clay bricks, much like other European countries [16].

\subsection{Geometrical characterization of Portuguese masonry infill walls}

For the geometric characterization of masonry enclosures, were used the data collected in two previous studies [5], [17], which analyzed design plants of reinforced concrete buildings built in Portugal.

Furtado et al. [17] analyzed 80 architectural and structural design drawings to collect geometric data about reinforced concrete elements, and masonry enclosures. For each building were collected the following parameters: the story height with emphasis on ground floor, that usually is different from the others, ground floor area, dimensions of columns and beams with information about the reinforcement, and slabs thickness. Furthermore, 1400 masonry infill walls, from the analyzed buildings, were studied to define the most common typologies of openings and make a geometric characterization of masonry infill walls. The main goal was to characterize these types of non-structural walls used in Portuguese construction practice.

The analyzed buildings are mainly located in the districts of Lisbon, Aveiro and Porto, and there are also buildings in the districts of Braga, Viseu, Coimbra and Leiria. These buildings 
were constructed between 1950 and 2010. The period between 1950 and 1960 represents $11,77 \%$ of the analyzed buildings, and represents the buildings constructed prior to the entry into force of any seismic regulation. 52,93\% of the analyzed buildings were constructed between 1960 and 1985, having been constructed with the first Portuguese seismic regulation [18]. The buildings constructed between 1985 and 2010, were designed with the most recent seismic regulation in Portugal [19], [20] before the Eurocode 8 [7]. The analyzed buildings constructed in this period from 1995 to 2010 represent $35.30 \%$. These percentages are very similar to those obtained from the 2011 census, for reinforced concrete buildings.

In the case of the number of floors, the analyzed buildings have a large amplitude from 2 to 10 floors, and most buildings have between 3 and 6 floors representing $70.6 \%$ of the analyzed buildings.

Turning now to the geometric features of buildings. From the analysis of the buildings, the authors concluded that normally the height of the ground floor, is different from the height of the remaining floors. It was possible to conclude that ground floor of buildings presents heights between $2,8 \mathrm{~m}$ and $3,5 \mathrm{~m}$. The most common height is $3,0 \mathrm{~m}$ representing $39,70 \%$ followed by $2,8 \mathrm{~m}$ with $25 \%$ of the buildings. The weighted average of the ground floor considering all the buildings is $3,19 \mathrm{~m}$. In terms of upper floors, the heights vary between $2,5 \mathrm{~m}$ and $3,0 \mathrm{~m}$. The most used heights are $2,7 \mathrm{~m}$ and $2,8 \mathrm{~m}$, representing almost $50 \%$ of the buildings. The weighted average for upper floors is $2.77 \mathrm{~m}$.

In terms of reinforced concrete structural elements, the authors collect information about beams and columns. For beams were collected the length, the height, the width and the reinforcement ratio of longitudinal reinforcement. For columns were collected information about the dimensions, width and depth, and reinforcement, longitudinal reinforcement ratio, and transversal reinforcement.

Beams length is usually conditioned by architectural options. For this study the authors, recorded beams with a length of $2.5 \mathrm{~m}$ to $6.5 \mathrm{~m}$. The most usual length is $5 \mathrm{~m}$ to be used in more than $26 \%$ of the elements analyzed. The great majority of buildings $(69.42 \%)$ have beams with lengths between $4 \mathrm{~m}$ and $5.5 \mathrm{~m}$. The weighted average for the length of the beams is $4.42 \mathrm{~m}$. Also, Pereira [5], in a similar study carried out on 24 reinforced concrete buildings, reported an average beam length of about $4.5 \mathrm{~m}$. In the case of beams height, the weighted average is $0,43 \mathrm{~m}$. Were observed beams height between $0.20 \mathrm{~m}$ and $0.55 \mathrm{~m}$, but the most used heights are $0,40 \mathrm{~m}$ and $0,45 \mathrm{~m}$, representing $44,59 \%$ of the analyzed beams. In terms of beams width, the most used width is $0.25 \mathrm{~m}$, the weighted average of all analyzed elements is $0.29 \mathrm{~m}$, having been observed widths between $0.15 \mathrm{~m}$ and $0.4 \mathrm{~m}$. The last parameter analyzed in beams was the reinforcement ratio. The reinforcement ratio from $0.50 \%$ to $0.75 \%$ is clearly the most used, with $20 \%$ more elements than the second most used 0.25 to $0.50 \%$. The weighted average value presents a value of $0.63 \%$.

For the columns, the authors analyzed the width, depth, longitudinal reinforcement ratio and transversal reinforcement. In terms of width there is a clear tendency to use the range between 0.25 and $0.30 \mathrm{~m}$, with values ranging from 0.15 to $0,40 \mathrm{~m}$. The weighted average width of the columns is $0.26 \mathrm{~m}$. In the case of depth, there is a greater dispersion of the values used in the analyzed columns. Values between $0.20 \mathrm{~m}$ and $0.55 \mathrm{~m}$ were observed. The weighted average has a value of $0.38 \mathrm{~m}$. In terms of longitudinal reinforcement ratios, the distribution is similar to beams, the interval 0.50 to 0.75 , is the one that presents greater number of elements analyzed in a clear distance for the other intervals. The weighted average has a value of $0.61 \%$. The distribution of the transversal reinforcement shows that all analyzed elements had transversal reinforcement made of stirrups with $6 \mathrm{~mm}$ rods, deferring only in the space between stirrups. The most common spacing is $0.15 \mathrm{~m}$, and was recorded in $40 \%$ of the columns, followed by $0.25 \mathrm{~m}$ spacing recorded in $24 \%$ of the analyzed columns. 
After characterizing the reinforced concrete elements, the authors worked on the characterization of the masonry infill walls of analyzed buildings. It was studied the presence of openings in this type of walls, identifying the most common typologies of walls, in more than 1400 studied walls. It was also studied the dimensions of the openings in the masonry panel. The authors identified thirteen different types of walls identified in Figure 3, which differ in the number of openings and their position in the masonry panel.

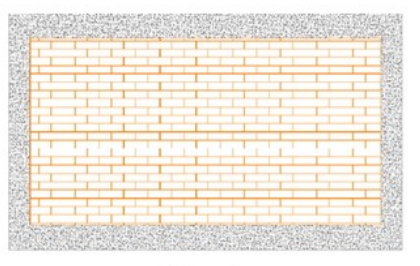

Type 1

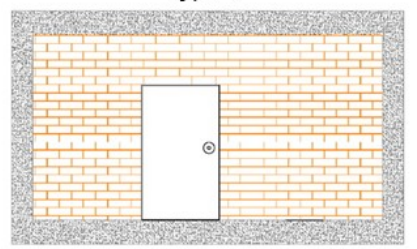

Type 4

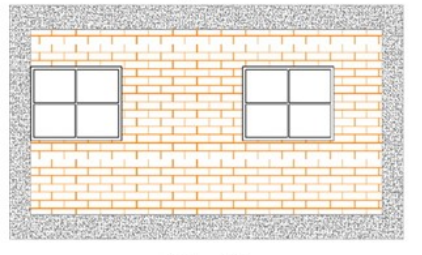

Type 7

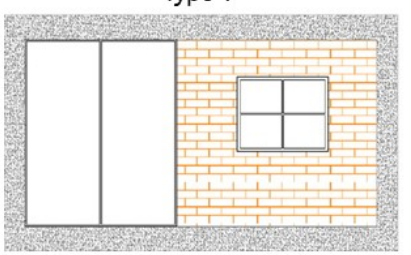

Type 10

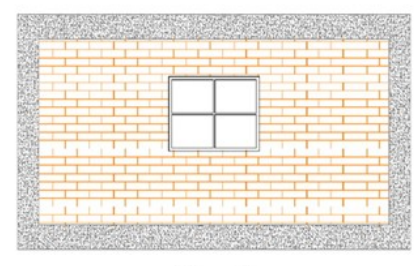

Type 2

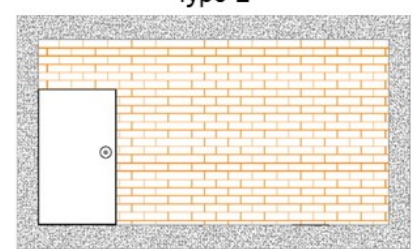

Type 5

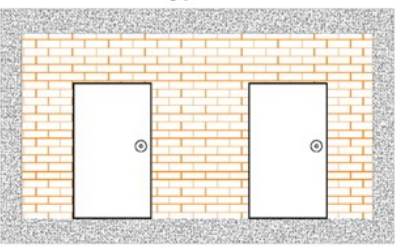

Type 8

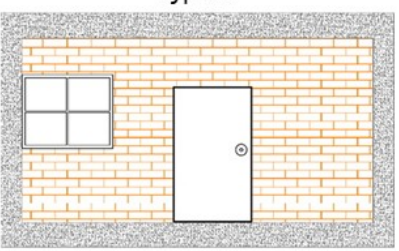

Type 11

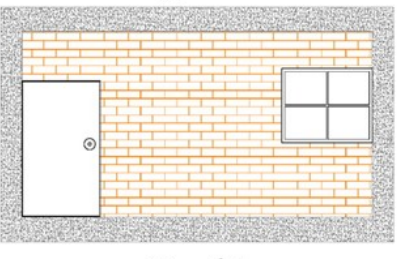

Type 13

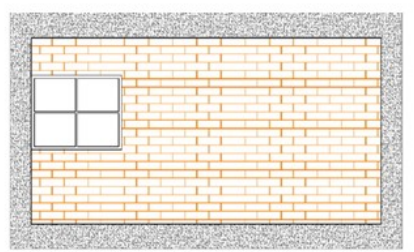

Type 3

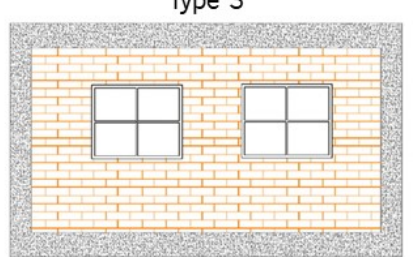

Type 6

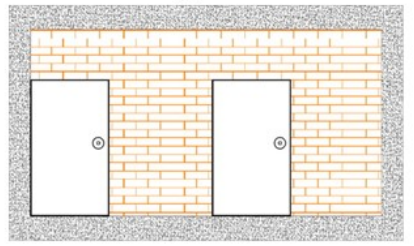

Type 9

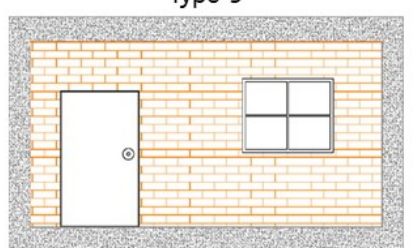

Type 12

Figure 3: Masonry infill wall types

From the 1400 masonry infill panels of the analysed buildings, it was concluded that panel type 1 and type 2 are the most used, each representing 17\% of the total of infill panels. From remaining typologies, types $6,8,4$ and 12 are highlighted, which stand out from the other typologies with $15 \%, 11 \%, 10$, and $9 \%$ respectively.

The distribution of openings height and width was measured in the infill panels. For openings height was registered openings ranging from $0.5 \mathrm{~m}$ to $2.5 \mathrm{~m}$. It was possible to identify the interval of $1.0 \mathrm{~m}$ to $1.5 \mathrm{~m}$ as the most common value of height for openings. The weighted average for the height of the openings in the panels is $1.43 \mathrm{~m}$. In the case of the width of the openings in the panels, there were openings with values from $0.5 \mathrm{~m}$ to $4 \mathrm{~m}$. But clearly the 
range of $1.5 \mathrm{~m}$ to $2.0 \mathrm{~m}$, and the range of $1.0 \mathrm{~m}$ to $1.5 \mathrm{~m}$, are the most common, absorbing over $60 \%$ of the analysed openings. The weighted average width of the openings is $1.80 \mathrm{~m}$.

In conclusion, the buildings constructed in the recent past in Portugal, are characterized by having a reinforced concrete structure, with an envelope made using masonry infill walls. In terms of characteristics, based on the studies presented previously, it can be said that a typical frame presents beams of $4.42 \mathrm{~m}$ with a section of $0.29 \mathrm{~m}$ width by $0.43 \mathrm{~m}$ of height with a reinforcement percentage of $0.63 \%$. In the case of columns, they have a height of $2.77 \mathrm{~m}$, with a section of $0.26 \mathrm{~m}$ wide by 0.38 deep. The longitudinal reinforcement has a value of $0.61 \%$ of the section area, and the transversal reinforcement is composed of $6 \mathrm{~mm}$ stirrups spaced of $0.15 \mathrm{~m}$. The openings have an average width of $1.8 \mathrm{~m}$ with a height of $1.43 \mathrm{~m}$, and $17 \%$ of the walls do not have any opening.

\section{SEISMIC VULNERABILITY OF MASONRY INFILL WALLS}

Despite all the advantages attributed to masonry infill walls constructed with ceramic units, it is often the case that these infill walls present several pathologies, namely excessive cracking and problems related with moisture, which are associated with the poor quality of the workmanship and the lack of detail in terms of design [14]. The occurrence of earthquakes has also demonstrated its inadequacy in terms of performance to the seismic action. Masonry infill walls are not considered as structural elements since they do not support vertical loads and therefore there are no specific rules or guidelines for their design and detail, including in Eurocode 6 [21]. However, when an earthquakes occur, these walls play an important role in the overall behavior of the building, generally having a positive influence on the overall behavior of the building increasing the lateral strength and stiffness, contributing also to energy dissipation [4]. If the damage of the walls is controlled, they can promote mechanisms of energy dissipation and control the relative displacements between floors. On the other hand, an irregular distribution of the walls in height, can lead to mechanisms of global collapse (soft story) or local collapse, at the level of the columns due to shear forces induced by infill walls (short pillar effect)[4].

Although masonry infill walls are not structural elements, individually they have to withstand seismic actions that are induced in the in-plane direction and in the out-of-plane direction [22]. The recent earthquakes in Lefkada in 2003 and Parnitha in 1999 in Greece, the earthquakes of Láquila 2009, Emilia in 2011 in Italy, and Christchurch in 2010 in New Zealand, showed an high level of damage for non-structural elements, with the masonry infill walls to present an inadequate seismic behavior.

Often the infill walls detach from the reinforced concrete elements and present diagonal cracking as a result of the relative displacement between floors incompatible with their deformation capacity and the development of stresses higher than the tensile strength of the masonry (see Figure 4). Sliding is also possible at the level of the mortar joints, as a result of the shear failure, leading to the detachment of the plaster. This cracking may or may not be repairable, depending on the density and thickness of the cracks. The behavior of the masonry infill walls presents a particular vulnerability to out-of-plane actions. For the seismic action is frequent the occurrence of a global collapse of masonry panel, as result of its rotation around the edges (beams and columns), which is associated with the poor connection between them and the infill wall. In the absence of adequate connection between the wall and the frame, it is impossible to develop the arch mechanism, typical of walls connected in two, three or four edges (unidirectional or bidirectional arch mechanism), which allows the wall to resist to outof-plane actions with considerable deformations without loss of stability [23]. The seismic vulnerability of infill walls is also associated with the lack of connection between the panels in the case of cavity walls. In this case, the two panels work independently and the high slen- 
derness results in fragile collapse of the panels, in particular of the external panel, (see Figure 4). Another aspect to be considered in the vulnerability of cavity walls consists of the poor support of the external leaf, when it is intended to use this for the correction of thermal bridges [10]. From the seismic point of view, inadequate support from the external leaf can contribute to accelerate the collapse of the wall in the out-of-plane direction. This type of collapse should be avoided because produce severe damages and loss of human lives.

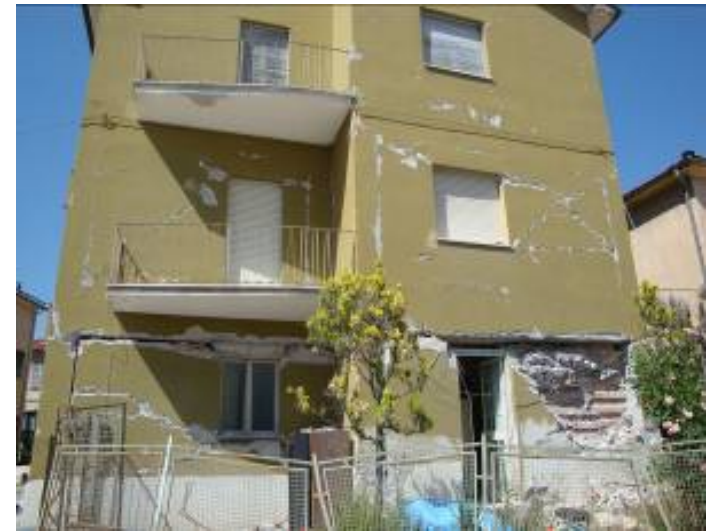

(a)

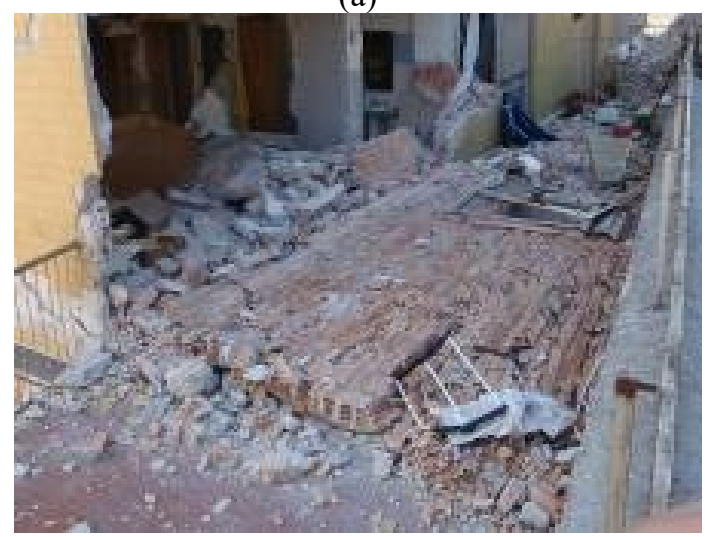

(c)

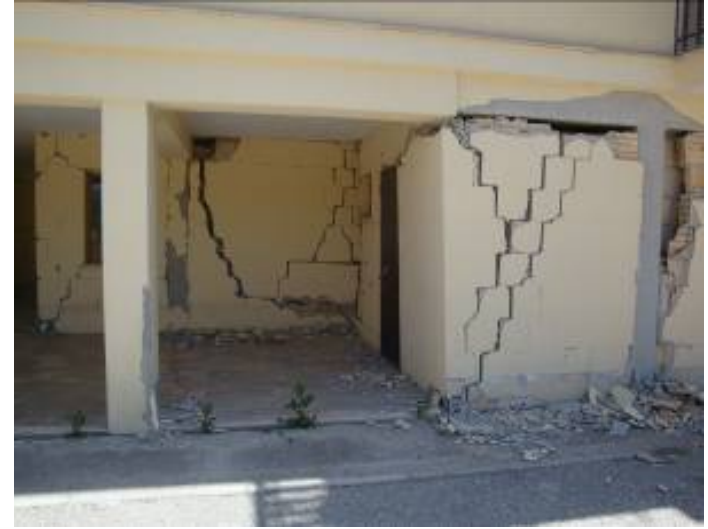

(b)

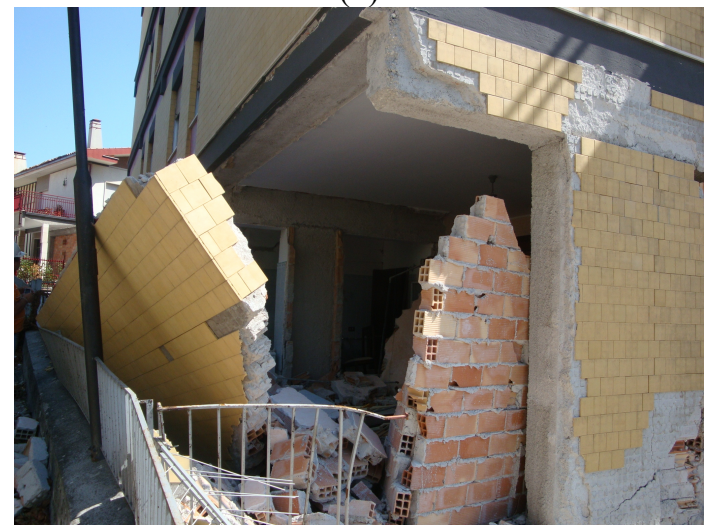

(d)

Figure 4: Masonry infill damage, (a) separation between infill and frame, (b) in-plane damage, (c) out-of-plane collapse, (d) out-of-plane failure.

\section{NEW SOLUTIONS FOR MASONRY INFILL WALLS}

To address these issues of seismic vulnerability in masonry infill walls, the INSYSME project (606229) has as the main objective the development of innovative systems for masonry enclosures walls that resist better to seismic action. These solutions are designed to be used in new construction, using traditional materials. This section focuses on the presentation of a new constructive system for masonry infill walls in Portugal in order to improve the seismic performance of masonry infill walls.

During the development of the new system, three main types of solutions have been identified for the development of innovative enclosure masonry systems. The main goal is to solve the above-mentioned problems arising under the point of view of seismic behaviour. Notwithstanding, problems and aspects also related to the service behaviour and to non-mechanical behaviour of the infill walls, are tackled.

The three main concepts on which the systems rely are: (1) keeping the enclosure wall rigidly attached (adherent) to the frame, but using either or both robust units and internal (mainly steel rebars, as in reinforced load bearing masonry) or external (mainly reinforced plasters) 
reinforcements; (2) keeping the enclosure wall rigidly attached (adherent) to the frame, or slightly disconnected, but allowing the internal deformation of the wall to occur, by means of special devices, special units, or special sliding or deformable vertical or horizontal joints; or (3) disconnecting the enclosure system from the top beam and/or from the columns, in order to allow relative displacements between the wall and the frame to occur without interactions. It is also possible create hybrid systems using more than one of the solution described above.

At University of Minho was created one system called UMSystem. The UMSystem proposed at university of Minho, also called Térmico system (see Figure 5), use the concept of maintain the infill rigidly attached to the frame, using internal reinforcement and connectors between the infill and frame. This system is a single-leaf clay masonry wall made with a commercial vertical perforated masonry unit produced in Portugal. The proposed system uses a M10 pre-mixed commercial mortar in the bed joints, and dry head joint with interlocking. To improve the in-plane and out-of-plane performance of masonry infill walls, truss reinforcements was used in the bed joints. Additionally, the walls are connected to the columns by metallic connectors at each two rows where bed joint reinforcement is applied. The masonry infill panel was built with $294 \times 187 \times 140 \mathrm{~mm}$ bricks with vertical perforation, using murfor RND 0.5100 reinforcement and in each two rows, and murfor $L+100$ anchors to connect the infill and RC frame at the same levels of reinforcements.

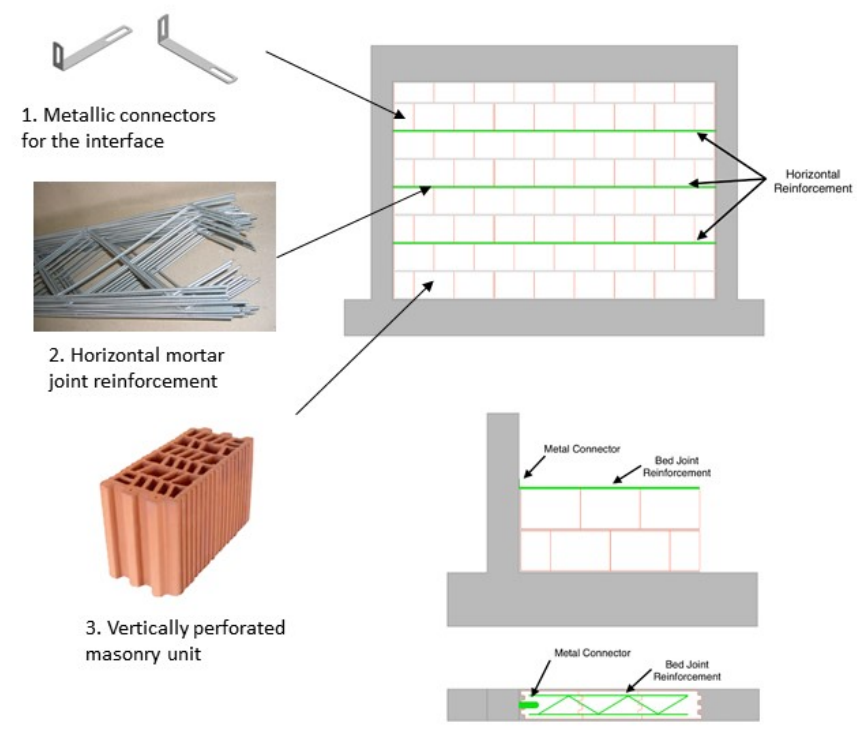

Figure 5: Masonry infill system proposed at University of Minho.

The idea of UMSystem is making the infill and the frame one system, increasing the initial stiffness by using connectors and reinforcement, which not only helps to increase the maximum load, as to control cracking and the out-of-plane collapse.

\section{EXPERIMENTAL PROGRAM}

\subsection{Description of the specimen}

The reinforced concrete frame considered in the present study is representative of the actual building practice in Portugal. The definition of the typical RC frame was based on an extensive work of geometrical characterization of Portuguese masonry infill presented in point 
2.2. Due to the laboratory limitations, it was decided to test reduced scale specimens $(2 / 3)$. For this, Cauchy's Similitude Law was considered. Therefore, the geometry of the frame was reduced to 1,5 times and the reinforcing scheme was updated so that the relation between resisting bending moments and shear resisting forces could be well correlated between full and 1:1,5 scale frames. The geometry and reinforcement scheme adopted for the $2 / 3$ scale RC frame are shown in Figure 6.

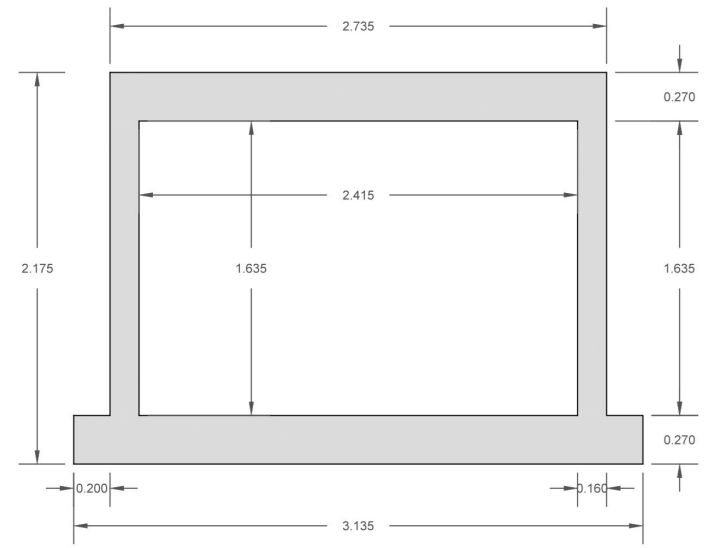

(a)

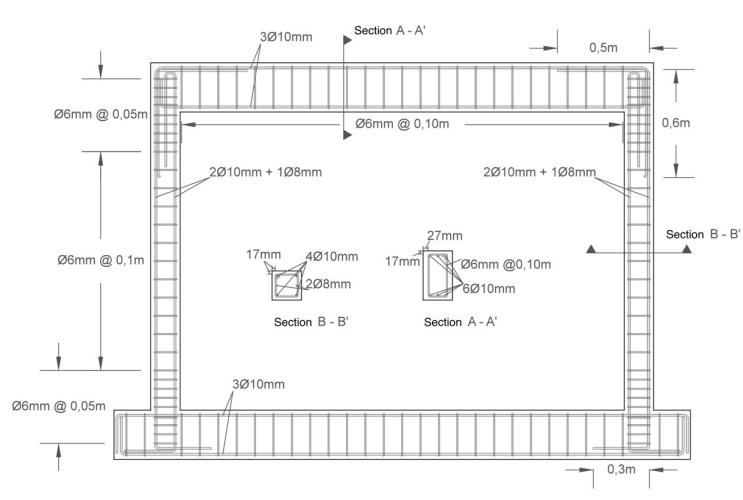

(b)

Figure 6: RC frame used in experimental tests, (a) geometric scheme, (b) reinforcement scheme.

The frame had $2575 \mathrm{~mm}$ and 1770 in length and height, respectively. The dimensions of beam and columns sections were $270 \times 160 \mathrm{~mm}$ and $160 \times 160 \mathrm{~mm}$, respectively. The masonry infill panel was built with $294 \times 187 \times 140 \mathrm{~mm}$ bricks with vertical perforation, using murfor RND 0.5100 reinforcement and in each two rows, and murfor $L+100$ anchors to connect the infill and RC frame at the same levels of reinforcements. The steel used for the construction of RC frame and for reinforcement of masonry infill panel was a A400NR, and A500NR. In case of concrete, a C55/67 class was used for the construction of the RC frame. A M10 mortar was adopted for the laying of the masonry units. The thickness of the horizontal joints was assumed to be $0,5 \mathrm{~cm}$. The mechanical proprieties of materials and masonry specimens was obtained at university of Minho by Silva et al. [24].

\subsection{Test setup and instrumentation}

The test setup for the in-plane loading of the infilled frames is shown in Figure 7(a). The infilled frame was placed on two separated steel beams of HEA300 that were firmly attached to the strong floor to avoid their sliding on the floor. The sliding of the infilled frame was prevented by bolting an L-shape steel profile to each side of the steel beam and its uplifting was also prevented by bolting two rectangular-shape steel profiles to the steel beams. The rectangular shape steel profile was made by welding two UNP140. The out-of-plane movement of the enclosure frame was restrained by putting the L-shaped steel frame on each side of the upper beam. Those profiles were bolted to the upper steel beams. Three rollers were placed on upper L-shaped profiles to minimize or even completely eliminate the friction between them and the upper reinforced concrete beam during in-plane loading.

Two vertical jacks were mounted on the top of the columns to apply the vertical load of $200 \mathrm{KN}$, corresponding to $30 \%$ of the column's axial force capacity. Those jacks are pinned to the lower steel beams by means of four vertical rods of $\Phi 16 \mathrm{~mm}$. A hydraulic actuator with capacity of $250 \mathrm{kN}$ was attached to the reaction wall to apply the in-plane cyclic loading to the specimen. A steel plate of $400 \times 300 \times 30 \mathrm{~mm}$ was connected to the hydraulic actuator that ap- 
plies the load in positive direction from right to left direction. This steel plate was connected to other one with the same dimensions by $2 \Phi 50 \mathrm{~mm}$ steel rods to enable to pull the specimen in the negative direction. These steel plates enable also to have a uniform distribution of the horizontal load in the cross-section of the upper beam.

An instrumentation scheme to measure the in-plane most relevant displacements during the in-plane testing is shown in Figure 7(b). Eighteen linear variable differential transformer (LVDT) devices were used to record the displacement in selected points. From them, two LVDTs were mounted on the masonry infill to measure the deformation of the infill (L1 and L2), and eight LVDTs were used to measure the relative displacement of the infill with respect to its surrounding frame (L3, L4, L5, L6, L7, L8, L9 and L10). The LVDTs L11 and L12 were placed to measure the sliding and uplifting of the infilled frame with respect to the steel profile. Four LVDTs L13, L14, L15 and L16 measure the sliding and uplifting of the steel profiles with respect to the strong floor. LVDTs L17 and L18 measure the horizontal displacement of the upper reinforced concrete frame.

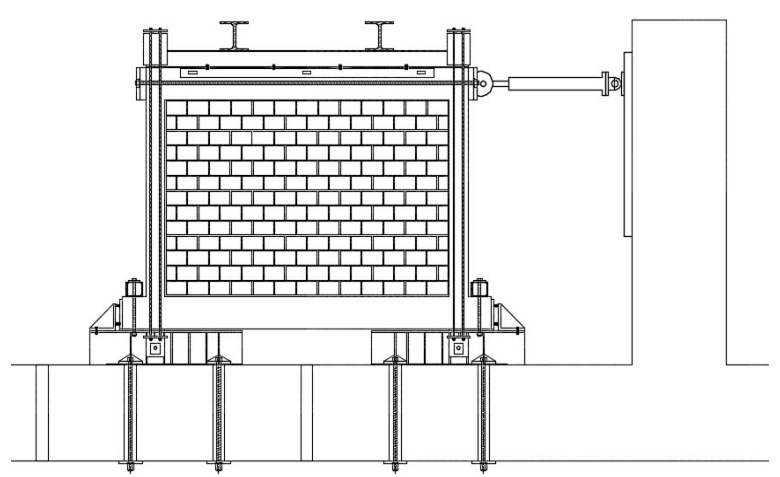

(a)

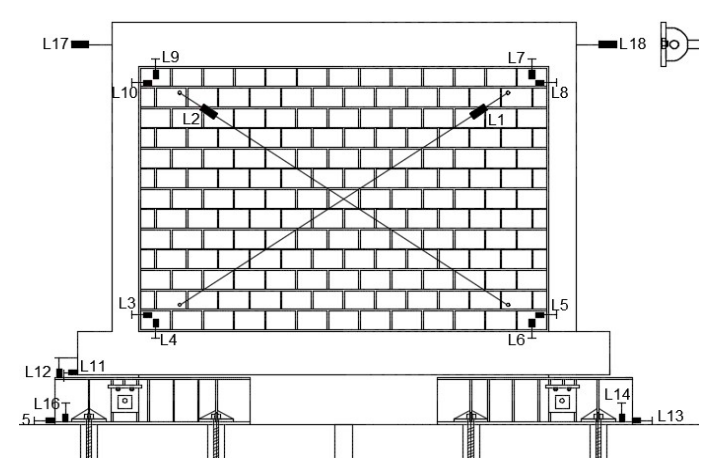

(b)

Figure 7: In-Plane test, (a) test setup for cyclic loading, (b) instrumentation scheme.

The test setup for out-of-plane loading is shown in Figure 8(a). The infilled frame was supported on the same steel profiles used for the in-plane testing setup. The out-of-plane restriction at the top and bottom RC beams was strengthened so that out-of-plane displacements at the boundaries could be prevented. For this, four steel rods connected to a steel device, connected in turn to the horizontal steel profiles were added at each side of the top RC beam, see Figure 8. The out-of-plane loading is applied by means of an airbag that is connected to an external supporting frame. Four rollers were mounted in the bottom part of the supporting frame enabling its moving along the direction of applied load without friction. The supporting frame was also kept in touch with four load cells to measure the load that is applied to the infill walls through the airbag, see Figure 8(a), where a detail about the system of the four load cells is shown (section A-A). The supporting frame, to which the load cells are attached, was firmly connected to the strong floor and to the lateral reaction wall, which prevented completely any uplifting and sliding of the out-of-plane reaction structure.

The instrumentation plan of the out-of-plane testing is shown in Figure $8(\mathrm{~b})$. A total number of fifteen LVDTs were placed on the specimen to monitor its deformation while the outof-plane load is applied. From them, nine LVDTs record the displacement history of the infill panel during loading (LVDT L1 to L9). Four LVDTs measure the relative displacement between infill and its surrounding frame (L10 to L13) and two LVDTs measure the out-of-plane movement of the upper and bottom reinforced concrete beam (L14 and L15). 


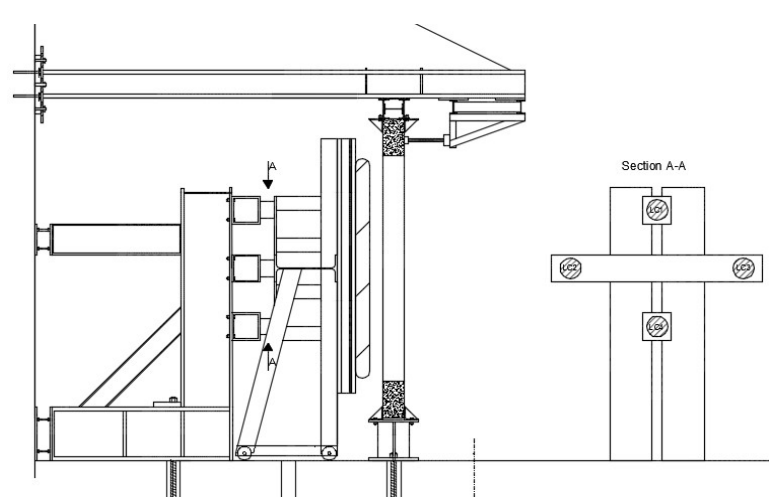

(a)

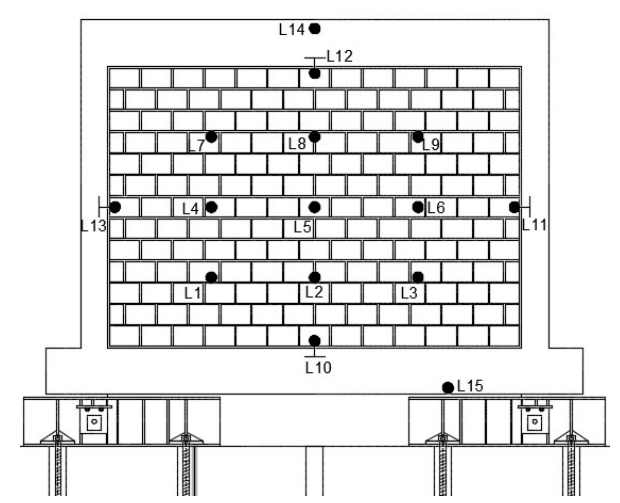

(b)

Figure 8: Out-of-Plane test, (a) test setup for cyclic loading, (b) instrumentation scheme.

\subsection{Loading pattern for in-plane and out-of-plane tests}

The in-plane testing was performed under displacement control by imposing different predefined levels of displacement by the hydraulic actuator, (see Table 1). The loading pattern was computed in accordance with FEMA 461 [25]. It is composed of sixteen different sinusoidal steps that starts from displacement of $0.5 \mathrm{~mm}(0.026 \%$ drift $)$ up to the lateral displacement of $75 \mathrm{~mm}$, corresponding to a lateral drift of 3.94\%. Each step was repeated two times except for the first step that repeated six times.

\begin{tabular}{cccc}
\hline Cycle & $\begin{array}{c}\text { Drift } \\
(\%)\end{array}$ & $\begin{array}{c}\text { Displacement } \\
(\mathrm{mm})\end{array}$ & \begin{tabular}{c} 
Number of repetitions \\
\hline 1
\end{tabular} \\
0.026 & 0.50 & 6 \\
2 & 0.037 & 0.70 & 2 \\
3 & 0.051 & 0.98 & 2 \\
4 & 0.072 & 1.37 & 2 \\
5 & 0.100 & 1.92 & 2 \\
6 & 0.141 & 2.69 & 2 \\
7 & 0.198 & 3.76 & 2 \\
8 & 0.277 & 5.27 & 2 \\
9 & 0.387 & 7.38 & 2 \\
10 & 0.542 & 10.33 & 2 \\
11 & 0.759 & 14.46 & 2 \\
12 & 1.063 & 20.25 & 2 \\
13 & 1.488 & 28.35 & 2 \\
14 & 2.083 & 39.69 & 2 \\
15 & 2.917 & 55.56 & 2 \\
16 & 3.937 & 75.00 & \\
\hline
\end{tabular}

Table 1: In-Plane loading pattern

The amplitude $a_{i+1}$ of step $i+1$ is 1.4 times of the amplitude $a_{i}$ of step $i$. Table 1 shows the drifts, the displacements and the number of repetitions for each cycle adopted for in-plane testing.

In the case of loading pattern for out-of-plane, a quasi-static cyclic testing (one cyclic direction), the same approach was used, being the test conducted also in displacement control [26]. The first amplitude was repeated for six times and the others repeated two times to investigate the strength degradation of the specimen at each displacement increment. The point selected to control the test was the midpoint of the masonry infill wall (mid height and at mid length). The loading was performed in one direction to monitor the deformation of the infill, propagation of the cracks and performance of the interfaces between infill and reinforced con- 
crete frame. In out-of-plane load pattern for the cycle sixteen the displacement used was $77.78 \mathrm{~mm}$, corresponding to a lateral drift of $4.08 \%$.

The experimental campaign is composed of two specimens to be tested under in-plane loading (a bare frame, and a RC frame with the UMSystem), and, one specimen to be tested under the out-of-plane loading.

\section{TEST RESULTS}

\subsection{In-Plane behavior}

The in-plane lateral force-displacement diagram obtained for UMSystem and Bare Frame during in-plane loading is shown in Figure 9. The forces recorded correspond to the load cell of the actuator placed at the middle height of the upper beam. In the case of the displacements, these correspond to the LVDT 18, also placed in the middle height of the upper beam.

As mentioned before, positive direction is the direction where the hydraulic actuator pushes the specimen, whereas the negative direction is the direction that the actuator pulls the specimen by two plates that connected with two thick rods.

This diagram presents some differences in the positive and negative directions. The specimen reached maximum load of $166.65 \mathrm{kN}(+147 \%$ than bare frame) at displacement of $19.83 \mathrm{~mm}$ corresponding to lateral drift of $1.04 \%$. After the peak load the lateral force decreased until a residual strength around $95 \mathrm{kN}$ for $55.56 \mathrm{~mm}$ displacement $(2.92 \% \mathrm{drift})$. On the other hand, for the negative direction, the specimen reached its peak load of $-155.25 \mathrm{kN}$ at displacement of $19.60 \mathrm{~mm}$ (lateral drift of $1.03 \%$ ). Lateral force was gradually decreased and reached a force around $-84 \mathrm{kN}$ at the displacement of $55.56 \mathrm{~mm}(2.92 \% \mathrm{drift})$.

The test stopped because of the non-repairable damage of infill, depicted also by a reduction of force that can be observed in Figure 9(a). The force response during the second cycle is almost the same of first cycle, for firsts steps of loading in elastic range of the wall. After these firsts' steps, it is possible to see the reduction for second cycle. This reduction is approx. $10.75 \%$ for positive direction and $10.63 \%$ for negative direction.

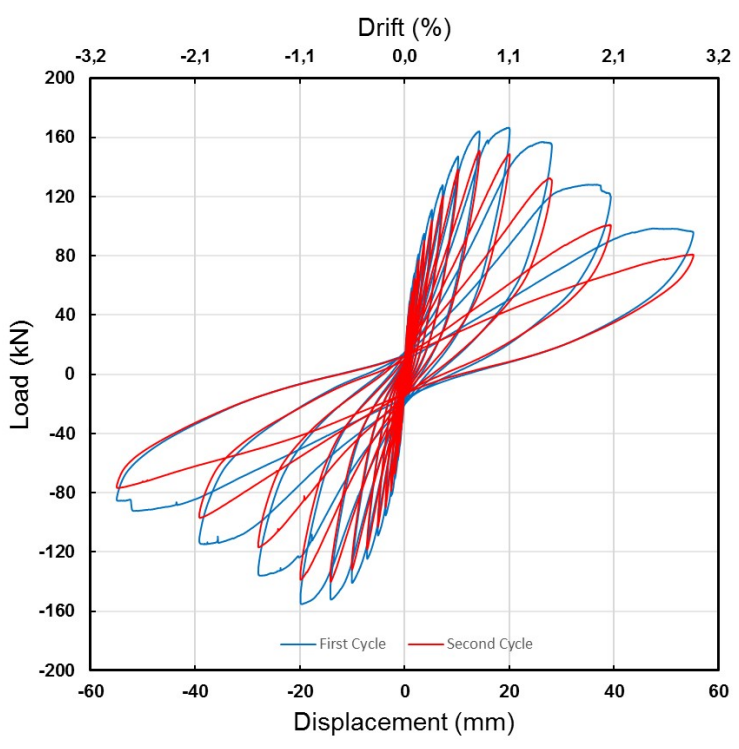

(a)

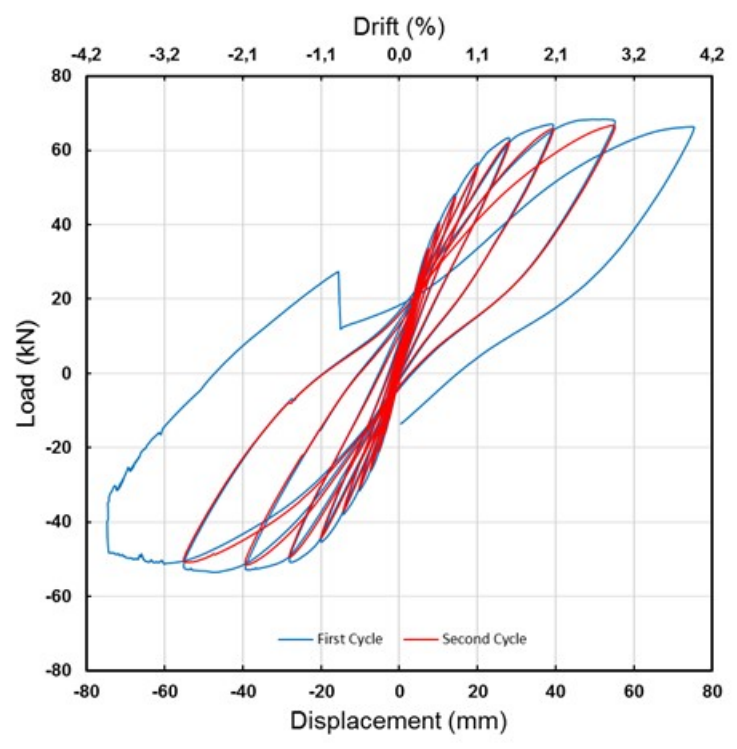

(b)

Figure 9: In-Plane force-displacement diagram, (a) UMSystem, (b)Bare Frame. 
To assess the influence of masonry infill wall in the global cyclic behavior, was carried out one in-plane test only in the bare frame. The force-displacement diagram obtained for Bare Frame is shown in Figure 9(b). By comparing the force-displacement diagrams for RC bare frame and $\mathrm{RC}$ infilled frame, it is observed that an increase on the lateral strength was observed in case of the RC infilled frame. The bare frame achieved a maximum load of $67.60 \mathrm{kN}$ at displacement of $53 \mathrm{~mm}$ corresponding to a lateral drift of $2.78 \%$. After the peak load was reached, a reduction of lateral load of about $17 \%$ was recorded at a displacement of about $75 \mathrm{~mm}(3.93 \% \mathrm{drift})$. For the negative direction, the specimen presents a similar behavior. The maximum load for this direction was $-54.38 \mathrm{kN}$ at displacement of $46.98 \mathrm{~mm}(2.47 \% \mathrm{drift})$. For the last cycle of $75 \mathrm{~mm}$ the lateral force was decreased for a value around $-52 \mathrm{kN}$.

Comparing these two in-plane tests, it is possible to conclude that the use of masonry infill wall means the increase on the lateral resistance of approximately $147 \%$. However, and as expected, the stiffness of infilled RC frame is higher than stiffness exhibited by the bare frame. The drift for maximum load is lower in the infilled frame, being of $1.04 \%$, while in bare frame the drift corresponding to the maximum lateral resistance was $2.78 \%$.

The damage patterns at different levels of displacement are presented in Figure 10. The damage pattern of infilled wall starts to be represented in Figure 10(a) at cycle 8, for a displacement of $7.32 \mathrm{~mm}$ corresponding to a lateral drift of $0.34 \%$. At this level of deformation, the cracking initiate at the interface between top beam and masonry infill, and in the interfaces between the columns and the infill wall, occurring the separation between the infill and the bare frame. After the damage begins by appearing in the central part of the wall and progress through the corners. In next cycles, the cracks increase their dimensions, and the damage in the interface between masonry infill and bare frame increase. The damage involves also some cracking at the brick units. At the end of the test in Figure 10(c) same parts of masonry units fall from the wall, this is more clearly in top of infill, and along the diagonal of the wall.

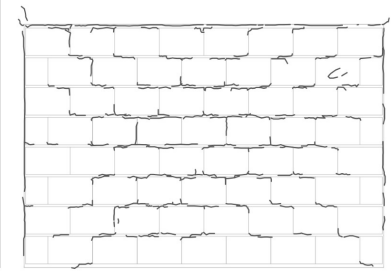

(a)

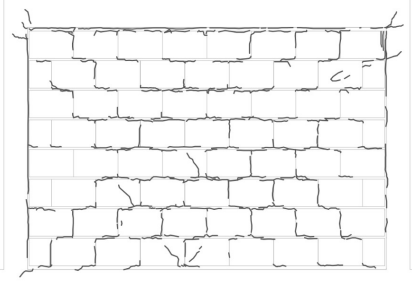

(b)

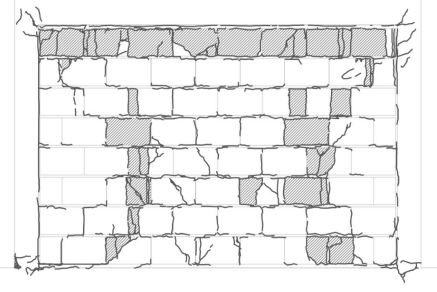

(c)

Figure 10: Damage pattern of UMSystem, (a) at $7.32 \mathrm{~mm}$, (b) at $14.35 \mathrm{~mm}$, (c) at $55.56 \mathrm{~mm}$.

For the bare frame the cracks start at cycle 8 , for a drift of $0.34 \%$ (7.32 mm displacement), at bottom part of columns. For increasing displacements, the cracks concentrate in the top intersections between the columns and beams.

\subsection{Out-of-plane behavior}

The force-displacement diagram for the out-of-plane test of UMSystem is shown in Figure 11. After an initial linear behavior, the response become nonlinear before the maximum load is reached. The system reached maximum load of $117.05 \mathrm{kN}$ at a displacement of $53.65 \mathrm{~mm}$ corresponding to lateral drift of $3.28 \%$. After the peak load, the behavior presents same softening, and the lateral force decreased until a resistance around $108 \mathrm{kN}$ for $64 \mathrm{~mm}$ displacement $(3.92 \%$ drift), before stopping the test. The maximum displacement applied was around $64 \mathrm{~mm}$, near to wall collapse. The test stopped because the imminent collapse of infill, depict- 
ed also by a reduction of force that can be observed in Figure 11. The force response during the second cycle is almost the same of first cycle, for firsts steps of loading in elastic range of the wall. After these firsts' steps, it is possible to see the reduction for second cycle. This reduction for maximum force has a value from approx. $6.59 \%$.

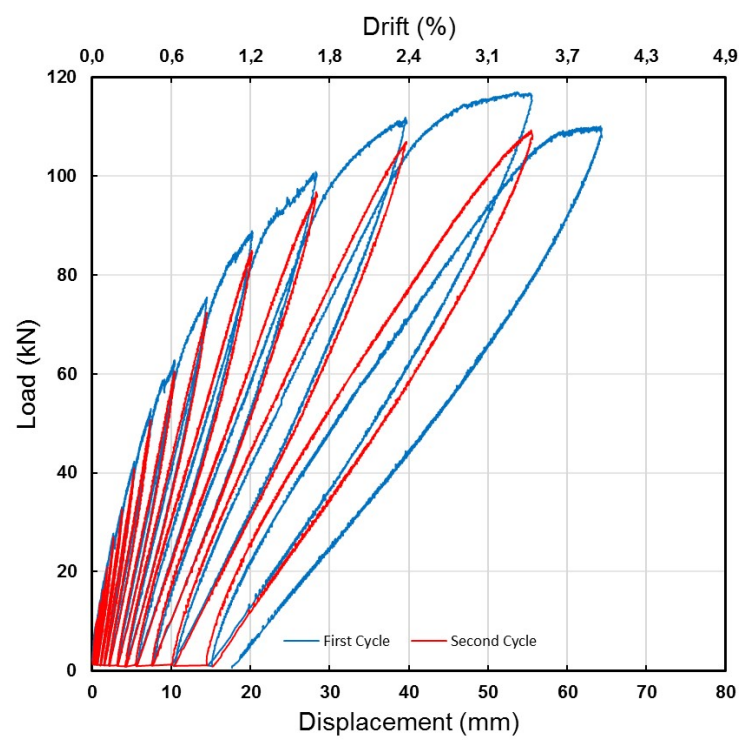

Figure 11. Out-of-Plane force-displacement diagram of UMSystem.

The damage patterns at different levels of displacement for the out-of-plane test are presented in Figure 12. The first cracks start to appear in central part of wall in cycle 9, $0.45 \%$ drift $(7.38 \mathrm{~mm})$. After this in next cycles until the final of test the cracks open from the central part to the corners of the wall. It is possible to observe the development of an arch mechanism in vertical direction. At the final stage of test, it's clearly stair step crack, progressing from the central part of the infill to the corners, as result of the development of the arching mechanism in the vertical and horizontal direction. Additionally, it is seen same cracks in the middle of the columns, that can result from que transmission of stress the occur due to the use of metal connectors between the infill and the columns.

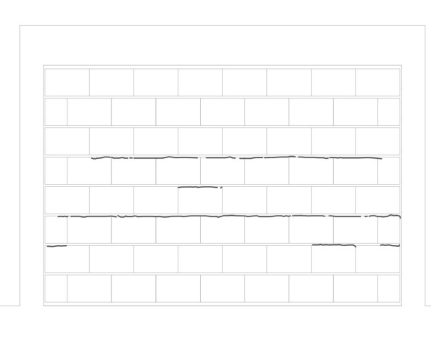

(a)

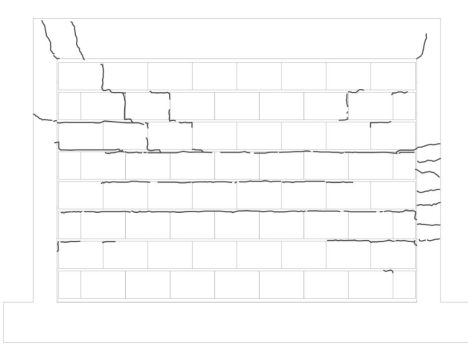

(b)

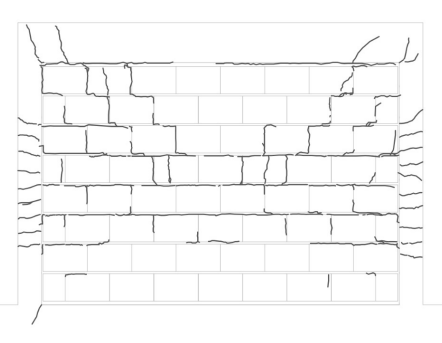

(c)

Figure 12: Damage pattern of UMSystem for out-of-plane tests, (a) at $7.38 \mathrm{~mm}$, (b) at 20.25mm, (c) at $64.37 \mathrm{~mm}$.

\subsection{Comparison with traditional cavity walls}

After briefly presenting the results obtained for UMSystem, to the In-Plane, and Out-ofPlane direction, it is important to compare the performance of the system, with the traditional solutions used in Portugal, in order to evaluate the performance of the UMSystem, compared to the current situation in Portugal. 
For this, were used the results of two tests performed by Akhoundi [27], in cavity walls that are representative of traditional solution applied in Portugal. This comparison is possible because the tests performed by Akhoundi uses a bare frame with de same dimensions of the bare frame used in UMSystem, and the tests were performed in the same laboratory of University of Minho following the same test procedure. The masonry panel tested by Akhoundi is a cavity wall, without any connection between the leafs, made with an external leaf of $80 \mathrm{~mm}$ and an inner leaf of $60 \mathrm{~mm}$, which gives que same cross section of UMSystem.

In the Figure 13, are presented the monotonic envelopes of the obtained from the experimental hysteric loops, of the in-plane and out-of-plane tests.

Comparing the monotonic envelopes obtained for in-plane test of UMSystem, with the envelops obtained for the traditional wall and bare frame (see Figure 13(a)), it is possible to conclude that the presence of a infill wall panel highly increases the stiffness and the maximum lateral force that the system can withstand. The UMSystem present the high value of lateral resistance, increase the value in $147 \%$ in relation to the bare frame, and $24 \%$ in relation to traditional cavity wall. The maximum lateral force on the traditional cavity wall is reached for a lower drift value $(0.54 \%)$, while for the UMSystem the maximum is reached for a drift of $1.04 \%$. The stiffness of the two systems is quite similar until the traditional wall approaches its maximum capacity. After reaching the maximum the tendency of the systems is to lose lateral resistance, approaching the behavior of the curve of the reinforced concrete frame, for great values of displacements.

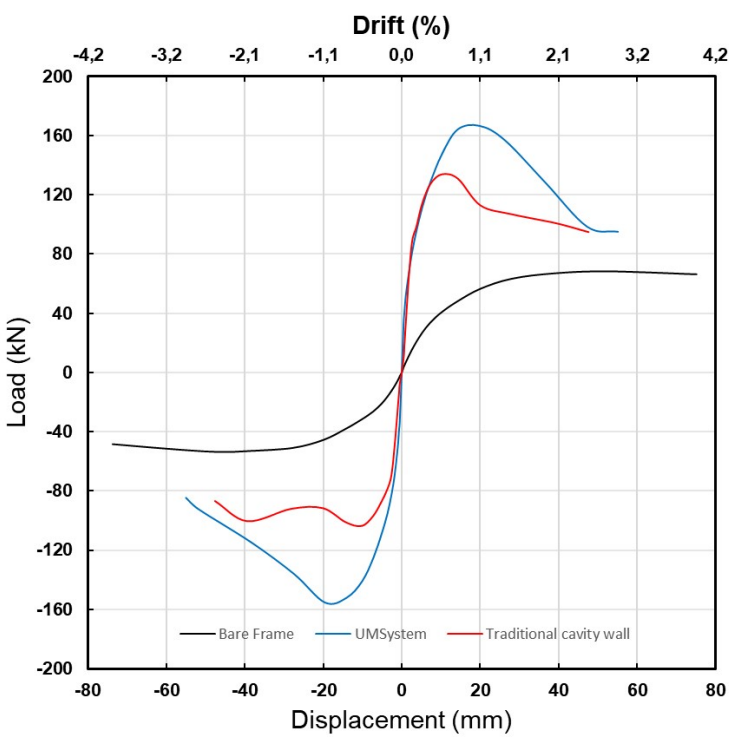

(a)

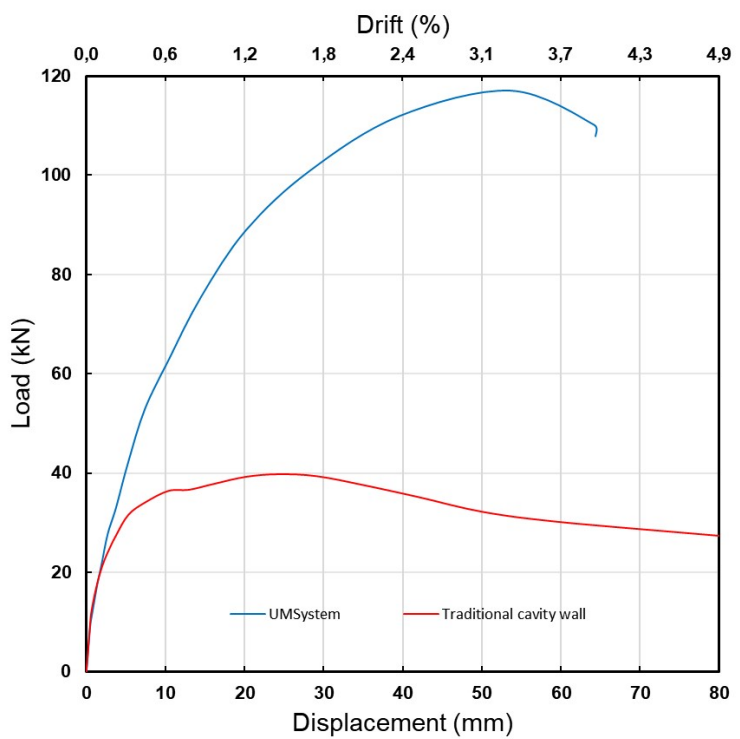

(b)

Figure 13: Force-displacement monotonic envelopes, (a) in-plane, (b) out-of-plane.

The monotonic envelopes obtained for out-of-plane test of UMSystem, and traditional wall are presented in Figure 13(b). From the comparison of the curves, it is possible to conclude that the UMSystem present a must larger value of lateral resistance, increase the value in $194 \%$ in relation to traditional cavity wall. This large difference can in part be explained by the operation of the traditional wall, where only the exterior leaf works, when the wall is subjected to out-of-plane loads. The maximum lateral force on the traditional cavity wall is reached for a lower drift value (1.48\%), while for the UMSystem the maximum is reached for a drift of $3.28 \%$, which shows the that UMSystem can accommodate large displacements before reach its maximum capacity. The stiffness of the two systems is similar in the initial 
phase for displacements lower than $3 \mathrm{~mm}$. After that the traditional wall approaches its maximum capacity, and the UMSystem continues the loading process. After reaching the maximum the tendency of the systems is to lose lateral resistance, the traditional cavity wall, have a great capacity of deformation reaching almost $80 \mathrm{~mm}$, of maximum displacement. In the case of the wall of the UMSystem, the loss of strength after the maximum is more pronounced, but the system can continue to accommodate deformation, to a value close to $65 \mathrm{~mm}$, when the test was stopped due to the eminence of collapse.

\section{CONCLUSIONS}

This paper presents and discuss same results obtained for in-plane and out-of-plane cyclic testing carried out on a new solution defined to improve masonry infilled RC frames. This system was developed by University of Minho in the scope of a European project INSYSME.

In the in-plane direction the masonry infill achieves higher resistance in about $24 \%$ than the traditional solution of cavity walls. The global behavior of hysteric curves was similar in the case of two systems, both presenting softening after peak load, but in case of strength degradation the traditional cavity wall presents more degradation. In case of stiffness, both systems presented similar values until the traditional wall approaches its maximum capacity.

For the out-of-plane direction, it was possible to apply a uniform load using an airbag, which is considered to be more representative of the out-of-plane lateral induced load by earthquakes. The resisting mechanism in both tests was an arching mechanism more evident in vertical direction. In both specimens it was possible to catch the post-peak behavior showing same softening. The UMSystem present a must larger value of lateral resistance, increase the value in $194 \%$ in relation to traditional cavity wall, which can be explained by the fact of only the external leaf of traditional wall be loaded, when the wall is subjected to out-of-plane test.

From the presented results, it can be concluded that this UMSystem, presents good indicators with respect to the seismic behavior, representing an improvement in the behavior, compared to the traditional cavity walls used in Portugal.

\section{ACKNOWLEDGMENTS}

The authors gratefully acknowledge the funding from the European Union's Seventh Framework Program for research, technological development and demonstration under grant agreement No 606229, which support this work.

This work was also supported by FCT (Portuguese Foundation for Science and Technology, within ISISE, project UID/ECI/04029/2013, and through a doctoral scholarship reference SFRH/BD/125094/2016.

\section{REFERENCES}

[1] S. Pompeu dos Santos, Enclosure Masonry Wall Systems Worldwide : Typical Masonry Wall Enclosures in Belgium, Brazil, China, France, Germany, Greece, India, Italy, Nordic Countries, Poland, Portugal, the Netherlands and USA. Taylor \& Francis Group, 2007.

[2] L. G. Jorquera, "Estudio experimental sobre la resistencia de muros de albãnileria sometidos a cargas horizontales," Rev. del IDIEM, vol. 3, 1964.

[3] A. E. Fiorato, M. a Sozen, and W. L. Gamble, "An Investigation of the Interaction of 
Reinforced Concrete Frames with Masonry Filler Walls,” 1970.

[4] E. . Vintzileou and T. P. Tassios, "Seismic behaviour and design of infilled R.C. frames," Eur. Earthq. Eng., pp. 22-28, 1989.

[5] M. F. P. Pereira, "Avaliação do desempenho das envolventes dos edifícios face à acção dos sismos," Universidade do Minho, 2013.

[6] G. . Lourenço, P. B.; Vasconcelos, P. . Medeiros, and J. Gouveia, "Vertically perforated clay brick masonry for loadbearing and non-loadbearing masonry walls.," Constr. Build. Mater., pp. 2317-2330, 2010.

[7] CT 115, "NP EN 1998-1: Eurocódigo 8 - Projecto de Estruturas para resistência aos sismos. Parte 1: Regras gerais, acções sísmicas e regras para edifícios," vol. 1. Instituto Português da Qualidade, 2010.

[8] G. Al-Chaar, M. Issa, and S. Sweeney, "Behavior of Masonry-Infilled Nonductile Reinforced Concrete Frames,” J. Struct. Eng., vol. 128, no. August, pp. 1055-1063, 2002.

[9] V. Bertero and S. Brokken, "Infills in seismic resistant building," J. Struct. Eng., vol. 109, no. 6, pp. 1337-1361, 1983.

[10] R. . Vicente, H. . Rodrigues, A. . Costa, H. . Varum, and M. da S. J. A. R., "Masonry enclosure walls: lessons learnt from the recent Abruzzo Earthquake," in 14th European Conference of Earthquake Engineering, 2010.

[11] C. Karakostas, V. Lekidis, T. M. T. Salonikios, I. Sous, and M. Demosthenous, "Seismic response of structures and infrastructure facilities during the Lefkada, Greece earthquake of 14/8/2003," Eng. Struct., vol. 27, no. 2, pp. 213-227, 2005.

[12] F. Braga, V. Manfredi, A. Masi, A. Salvatori, and M. Vona, "Performance of nonstructural elements in RC buildings during the L'Aquila, 2009 earthquake," Bull. Earthq. Eng., vol. 9, no. 1, pp. 307-324, 2011.

[13] G. . Magenes et al., "Preliminary damage survey to masonry structures after the May 2012 Emilia earthquakes. v1,” 2012.

[14] J. A. R. Mendes da Silva, "Alvenarias Não Estruturais: Patologias e Estratégias de Reabilitação," in Seminário sobre Paredes de Alvenaria, 2002, pp. 187-206.

[15] A. B. Dias and A. V. S. Sousa, Manual de Alvenaria de Tijolo. Associação Portuguesa de Indústria Cerâmica, 2009.

[16] F. da R. P. dos Santos, "Alvenarias em edifícios - Inventariação das soluções utilizadas e proposta de um novo sistema," Universidade do Porto, 1998.

[17] A. Furtado, C. Costa, A. Arêde, and H. Rodrigues, "Geometric characterisation of Portuguese RC buildings with masonry infill walls," Eur. J. Environ. Civ. Eng., vol. 20, no. 4, pp. 396-411, 2016.

[18] RSCCS, "Regulamento de segurança das construções contra os sismos.” 1958.

[19] RSA, "Regulamento de segurança e acções para estruturas de edifícios e pontes." 1983.

[20] REBAP, "Regulamento de estruturas de betão armado e pré-esforçado.” 1983.

[21] CT115, "NP EN 1996-1-1: Eurocódigo 6 - Projecto de estruturas de alvenaria Parte 1-1: Regras gerais para alvenaria armada e não armada.” Instituto Português da Qualidade, 
2010.

[22] R. Angel, "Behavior of Reinforced Concrete Frames With Masonry Infills," University of Illinois, 1994.

[23] Y. H. Tu, T. H. Chuang, P. M. Liu, and Y. Sen Yang, "Out-of-plane shaking table tests on unreinforced masonry panels in RC frames," Eng. Struct., vol. 32, no. 12, pp. 39253935, 2010.

[24] I. Conference, E. Mechanics, N. Congress, E. Mechanics, and S. Gomes, "CHARACTERIZATION OF MATERIALS AND MASONRY ASSEMBLAGES FOR SEISMIC RESISTANT MASONRY INFILLS,” no. November, pp. 781-796, 2018.

[25] FEMA461, "Interim Testing Protocols for Determining the Seismic Performance Characteristics of Structural and Nonstructural Components," no. June. 2007.

[26] F. Akhoundi, G. Vasconcelos, P. B. Lourenço, C. Palha, and L. Silva, "In-plane and out-of-plane experimental characterization of RC masonry infilled frames," in Proceedings of the 6th International Conference on Mechanics and Materials in Design, 2015, pp. 427-440.

[27] F. Akhoundi, "Seismic Strengthening of Old Masonry Infilled Reinforced Concrete Frames," 2016. 